\title{
PHANTON LIMB SENSATION UNDER SUBARACHNOID AND EPIDURAL ANALGESIA - A COMPARATIVE CLINICAL STUDY OF TWO HUNDRED CASES
}

\author{
Sudha Khurana, C.V. Singh, B. Chhabra, and G.L. Kamra
}

THE PHENOMENON of phantom limb is well documented. However, nowhere can one find a description or an explanation of the phantom sensation, so commonly observed during subarachnoid analgesia. In this study an attempt has been made to understand the psychological implications of motor and proprioceptive blockade following subarachnoid and epidural analgesia. Such understanding can help patients to overcome their difficulties during the period of block.

\section{METHODOLOGY}

Two hundred patients scheduled for elective surgical procedures under subarachnoid or epidural analgesia were selected at random. Demographic data are listed in Table I. All patients received atropine and promethazine in appropriate doses for premedication $\mathbf{4 5}$ minutes before the block. One hundred patients were given subarachnoid analgesia with 5 per cent hyperbaric lidocaine in doses ranging from one to two $\mathrm{ml}$ with a mean of $1.2 \pm 0.2 \mathrm{ml}$ or $60 \pm 1 \mathrm{mg}$. The remaining hundred received epidural block with 1.5 per cent or 2 per cent lidocaine with adrenaline. The mean dose of the 1.5 per cent solution was $28.55 \pm 5.3 \mathrm{ml}$ or $428 \pm 79.5 \mathrm{mg}$, while that of 2 per cent solution was $36.6 \pm 4.8 \mathrm{ml}$ or 732 $\pm 96 \mathrm{mg}$.

The subarachnoid blocks were done with the patients in the lateral recumbent position. Immediately after the block, 30 patients were turned supine with one or the other lower extremity flexed onto the abdomen, 20 were placed in lithotomy position, and the remaining 50 patients were kept supine (Table II).

The following observations were made and recorded: (1) pre-blockade position; (2) position at the time of motor blockade; (3) time of sensory block; (4) time of onset of motor blockade.

Sudha Khurana, M.D., D.A., C.V. Singh, D.A., M.S., B. Chhabra, D.A., M.S., G.L. Kamra, Professor (Deceased).

Department of Anaesthesiology, Medical College. Rohtak (Haryana), India.

Address for Reprints: Dr. C.V. Singh, 17/9J Medical College Enclave, Rohtak (Haryana).

Canad. Anaesth. Soc. J., vol. 26, no. 2, March 1979
During and after the surgical procedure the following questions were asked:

(1) How do you feel? Are you comfortable? (2) Does your lower limb feel - Normal? - Truncated or absent? - Flexed or absent? - Knee flexed?

The patients who experienced phantom sensation were further interrogated regarding the return of motor power and of normal position sense.

\section{Observations}

Fifty of the 100 patients with subarachnoid block were supine with leg extended (neutral position) at the time of motor blockade. Twenty of these no longer appreciated the existence of legs, while the other 30 patients were conscious of the position of their limbs. Of the remaining $\mathbf{5 0}$ patients, 30 were placed supine immediately after the block, with one of the lower limbs flexed over the abdomen at the time of motor blockade. Of these 30 patients, 25 experienced a painless flexed phantom limb which persisted throughout the motor blockade. Twenty other patients were in lithotomy position at the time of the motor blockade and 16 of these experienced fiexed knee phantom (Table II).

Of the I00 patients under epidural analgesia, only the two per cent lidocaine group felt as if their legs were no longer there and all others were able to move their toes on command. No phantom was perceived (Table III). Patients who had Iost an appreciation of their legs as well as those with positive phantom sensation required psychological support by assurance or diazepam $10 \mathrm{mg}$ or morphine $5 \mathrm{mg}$ intravenously (Tables IV and $V$ ).

\section{Discussion}

The painful phantom is in no way related to the proprioceptive phantom.' The cause of painful phantom has been ascribed to neuroma, an abnormal excitation of the pain pathways in amputated limb, irritation of the cut ends of sensory trunks and supraspinal disturbances. ${ }^{2}$ 
KHURANA, et al.: PHANTOM LIMB SENSATION

TABLE I

AGe ANd SeX InCIDENCE

\begin{tabular}{|c|c|c|c|c|c|c|c|}
\hline \multirow{2}{*}{$\begin{array}{c}\text { Age group } \\
\text { (years) }\end{array}$} & \multicolumn{3}{|c|}{ Male } & \multicolumn{3}{|c|}{ Female } & \multirow[b]{2}{*}{ Percentage } \\
\hline & Subarachnoid & Epidural & Total & Subarachnoid & Epidural & Total & \\
\hline $\begin{array}{l}\text { Under } 20 \\
21-40 \\
41-60 \\
60+\end{array}$ & $\begin{array}{r}10 \\
32 \\
8 \\
7\end{array}$ & $\begin{array}{r}3 \\
31 \\
10 \\
6\end{array}$ & $\begin{array}{l}13 \\
63 \\
18 \\
13\end{array}$ & $\begin{array}{r}-28 \\
10 \\
5\end{array}$ & $\begin{array}{r}3 \\
25 \\
18 \\
4\end{array}$ & $\begin{array}{r}3 \\
53 \\
28 \\
9\end{array}$ & $\begin{array}{r}8 \\
58 \\
23 \\
11\end{array}$ \\
\hline Total & 57 & 50 & 107 & 43 & 50 & 93 & 100 \\
\hline
\end{tabular}

TABLE II

Phantom Sensation under Subarachmold Analgesia

\begin{tabular}{|c|c|c|c|c|c|c|c|}
\hline \multirow{3}{*}{$\begin{array}{l}\text { Number } \\
\text { of } \\
\text { Patients }\end{array}$} & \multirow{3}{*}{$\begin{array}{l}\text { Position at } \\
\text { time of motor } \\
\text { blockade }\end{array}$} & \multicolumn{6}{|c|}{ Sensation after motor block } \\
\hline & & \multicolumn{2}{|c|}{ No sensation } & \multicolumn{2}{|c|}{ Phantom } & \multicolumn{2}{|c|}{ No phantom } \\
\hline & & Number & Per cent & Number & Per cent & Number & Per cent \\
\hline $\begin{array}{l}50 \\
30\end{array}$ & $\begin{array}{l}\text { Supine } \\
\text { Flexed limb }\end{array}$ & 20 & 40 & - & - & 30 & 60.00 \\
\hline $\begin{array}{r}20 \\
\text { Total }\end{array}$ & $\begin{array}{l}\text { on abdomen } \\
\text { Lithotomy }\end{array}$ & $\frac{-}{20}$ & - & $\begin{array}{l}25 \\
16 \\
41\end{array}$ & $\begin{array}{l}83.33 \\
80.00\end{array}$ & $\begin{array}{r}5 \\
4 \\
39\end{array}$ & $\begin{array}{l}16.66 \\
20.00\end{array}$ \\
\hline
\end{tabular}

TABLE III

Phantom Sensation under Epidural Analgesia

\begin{tabular}{cccccccr}
\hline \hline \multirow{2}{*}{$\begin{array}{c}\text { No. of } \\
\text { cases }\end{array}$} & $\begin{array}{c}\text { Concentration } \\
\text { Lidocaine }\end{array}$ & $\begin{array}{c}\text { Position at } \\
\text { time of motor } \\
\text { blockade }\end{array}$ & $\begin{array}{c}\text { No } \\
\text { sensation }\end{array}$ & Present & Per cent & Absent & Per cent \\
\hline 25 & $1.5 \%$ & Supine & - & - & - & 25 & 100 \\
25 & $1.5 \%$ & Lithotomy & & - & - & 25 & 100 \\
25 & $2 \%$ & Supine & 2 & - & - & 23 & 92 \\
25 & $2 \%$ & Lithotomy & & - & - & 25 & 100 \\
\hline
\end{tabular}

TABLE IV

Treatment of Phantom Sensation under Subarachnotd Analgesta

\begin{tabular}{|c|c|c|c|c|c|c|c|c|}
\hline \multirow{2}{*}{$\begin{array}{l}\text { No. of } \\
\text { cases }\end{array}$} & \multirow[b]{2}{*}{ Position } & \multicolumn{2}{|c|}{ Phantom } & \multicolumn{2}{|c|}{ No sensation } & \multirow[b]{2}{*}{ Assurance } & \multirow[b]{2}{*}{ Diazapam } & \multirow[b]{2}{*}{ Morphine } \\
\hline & & No. & Pef cent & No. & Per cent & & & \\
\hline 50 & $\begin{array}{l}\text { Other than } \\
\text { neutral }\end{array}$ & 41 & 82 & - & - & 5 & 15 & 21 \\
\hline 50 & Supine & - & - & 20 & 40 & 16 & 2 & 2 \\
\hline
\end{tabular}

TABLE $V$

Treatment of Phantom Sensation Under Epidural

\begin{tabular}{|c|c|c|c|c|c|c|c|}
\hline $\begin{array}{l}\text { No, of } \\
\text { cases }\end{array}$ & $\begin{array}{c}\text { Concentration } \\
\text { of solution }\end{array}$ & Position & Phantom & No sensation & Assurance & Diazapam & Morphine \\
\hline 25 & $1.5 \%$ & Supine & - & - & $一$ & - & - \\
\hline 25 & $1.5 \%$ & Lithotomy & 一 & - & - & - & - \\
\hline 25 & $2 \%$ & Supine & - & 2 & 1 & 1 & - \\
\hline 25 & $2 \%$ & Lithotomy & - & - & - & - & - \\
\hline
\end{tabular}


An attempt has been made in this study to understand the psychological components of motor and proprioceptive blockade following subarachnoid and epidural analgesia, to help the patient to interpret and to cope with the abnormal sensation which he or she experiences.

Gasser and Erlanger ${ }^{3}$ showed that the susceptibility of nerve tissue to blockade depends on fibre size. Ehrenberg ${ }^{4}$ has corroborated this by showing that the time required for blockade of a nerve varies inversely with the concentration of the drug and directly with the square of the radius of the nerve. The sequence of nerve block begins with autonomic nerves, followed by temperature (cold before warm), pain, touch, pressure, motor and last, proprioceptive fibres. ${ }^{5}$

For our purpose we have considered proprioceptive and motor blockade as occurring simultaneously. It would appear that the last impulses received by proprioceptive fibres before blockade are "locked in" with onset of the block.

If the patient was turned supine with legs extended before motor blockade occurred, phantom sensation failed to appear. If the patients legs were in any other position (limb flexed over the abdomen or lithotomy), that position appeared indelibly imprinted on the patient's mind until the block had worn off.

Positive appreciation of the position of the limb occurs only when a stimulus is received from the periphery. With subarachnoid analgesia peripheral stimuli from the lower extremities are blocked. Appreciation of that limb then depends on the proprioceptive impulses. If the proprioceptive fibres are blocked while the legs are extended in the supine position there is no disturbance of proprioception, no appreciation of peripheral stimuli, and the legs cease to exist so far as the patient is concerned. On the other hand, if proprioceptive blockade takes place while the legs are in any other position, this abnormal position is "locked in" until proprioception returns."

\section{SUMMARY}

Two hundred patients scheduled for various surgical procedures, under subarachnoid and epidural anaesthesia were divided in two groups of 100 for each technique. Subarachnoid analgesia was obtained with five per cent lidocaine, while epidural analgesia was accomplished with 1.5 per cent or 2 per cent lidocaine with adrenaline.

: This study shows that phantom sensation is painless and self limiting and that it lasts only for the duration of motor and proprioceptive blockade. It does not require any special treatment except psychotherapy, supplemented if needed by tranquillizers. Patients should be positioned after motor blockade has been established.

\section{RÉSUMÉ}

Nous avons étudié deux groupes de patients ayant subi des interventions diverses sous anesthésie rachidienne (100 patients) ou sous péridurale (100 patients). Les blocs ont été produits au moyen de lidocaine à 5 pour cent pour les rachidiennes, et à 1.5 ou 2 pour cent pour les péridurales. L'étude a démontré que la sensation de membre-fantôme sous rachi-anesthésie ou sous anesthésie péridurale est indolore, qu'elle disparaît d'elle-mème et que sa durée ne dépasse pas celle des blocs moteurs et proprioceptifs. Les patients ne requièrent aucun traitement spécial autre que d'être rassurés et, si besoin, un tranquillisant. On devrait attendre que le bloc moteur soit bien établi avant de placer les patients en position pour la chirurgie.

\section{REFERENCES}

1. Jorce-Riding. Phantom limb. Some theories. Anaesthe sia, 31: 102-106.(1976).

2. Melzack, R. \& Wall, P.D. Pain mechanism. A theory, Science $/: 50,971$ (1960).

3. Gasser, H.S. \& ERLAnGer, J. Role of fiber size in establishment of nerve block by pressure or cocaine, Amer. J. Physiol.. 88: 581 (1929).

4. Ehrengerg, L. Time concentration curve of local anaesthetic. Acta Chem. Scind. . 2: 63 (1948).

5. ADRIANI, J. The clinical pharmacology of local anaesthesia. Cl. Pharmacol. Ther., 1 ; 643 (1960).

6. Stephen, J., Prevonik, M.D., \& Eckenhoff, JAMES E. Phantom sensation during spinal anesthesia, Anesthesiology, 25: 767 (1964). 